\title{
Why Is the Labor Share Declining?
}

Sangmin Aum and Yongseok Shin

The fraction of national income accruing to labor (the labor share) had been roughly constant in developed economies for much of the 20th century but has fallen since the 1980s. We review several of the leading explanations in the literature for the declining labor share. We then point to hitherto unexplored dimensions of the data and provide suggestive evidence for a new explanation. In particular, we show that the labor share began a steeper descent in 2000. This more recent break in the laborshare trend coincides with the rapid rise of software investment, which has left a larger impact on service industries (than manufacturing) and on high-skill, cognitive occupations (than middle-skill, routine occupations). (JEL E25, O33)

Federal Reserve Bank of St. Louis Review, Fourth Quarter 2020, 102(4), pp. 413-28.

https://doi.org/10.20955/r.102.413-28

\section{INTRODUCTION}

For much of the 20th century, the fraction of national income accruing to labor (the labor share, hereafter) remained more or less constant over time, at least in developed economies. Keynes (1939, p. 48) wrote that "the stability of the proportion of the national dividend accruing to labour" was "one of the most surprising, yet best-established, facts in the whole range of economic statistics, both for Great Britain and for the United States.” Phelps Brown and Hart (1952) confirmed this fact, which was then cited by Kaldor (1957) and became widely known as one of the six Kaldor facts of economic growth. Although it is true that the labor share did not have an obvious long-term trend, it did exhibit deviations from its long-run level that lasted over a decade, a fact Kaldor was aware of. For example, he cited the mediumrun trends in the labor share in the 1930s, as documented by Kuznets (1952).

The labor share in the United States started to decline following its post-war peak in 1970 but, as Figure 1 shows, occasional reversals make it hard to precisely point out the beginning of the downward trend.

Sangmin Aum is an assistant professor of economics at Myongji University. Yongseok Shin is a professor of economics at Washington University in St. Louis and a research fellow at the Federal Reserve Bank of St. Louis. The authors thank the Review editor-in-chief and an anonymous referee for their helpful editorial suggestions.

(c) 2020, Federal Reserve Bank of St. Louis. The views expressed in this article are those of the author(s) and do not necessarily reflect the views of the Federal Reserve System, the Board of Governors, or the regional Federal Reserve Banks. Articles may be reprinted, reproduced, published, distributed, displayed, and transmitted in their entirety if copyright notice, author name(s), and full citation are included. Abstracts, synopses, and other derivative works may be made only with prior written permission of the Federal Reserve Bank of St. Louis. 
Figure 1

Labor Income Share in the United States

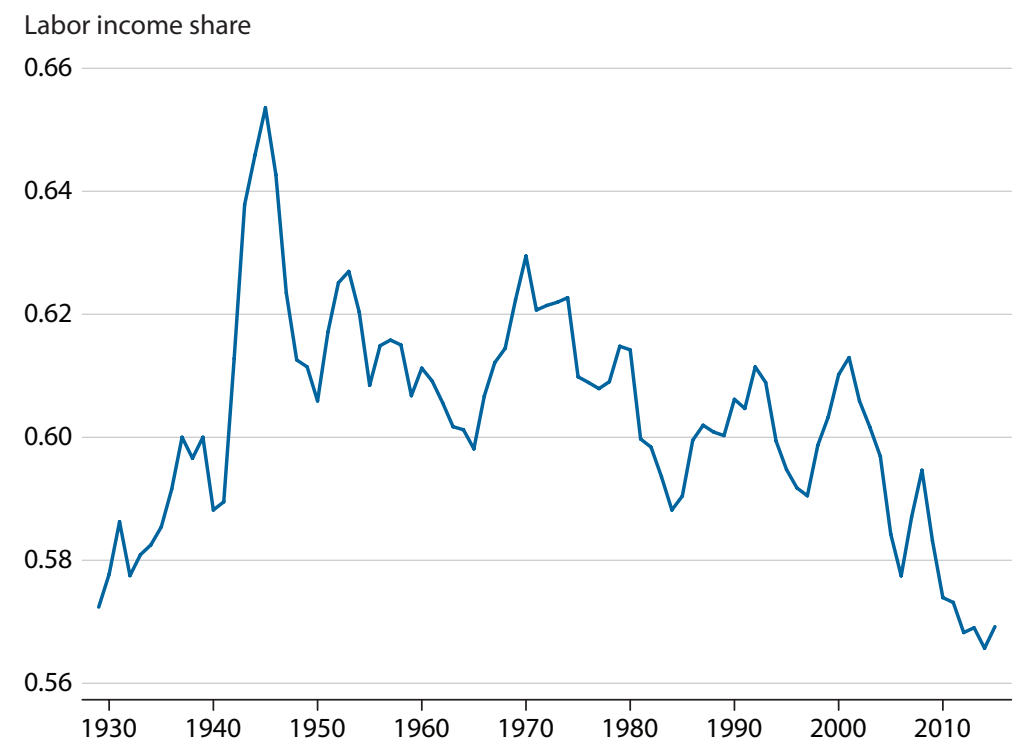

NOTE: Labor income share is the compensation of employees divided by gross domestic income. Proprietors' income is adjusted assuming that its labor share is the same as the labor share in the rest of the economy.

SOURCE: Authors' calculations based on data from NIPA.

In any case, economists did not pay much attention to the emerging downward trend in the labor share through the 2000s. It was only in the aftermath of the 2007-09 Financial Crisis, with heightened interest in economic inequality, that the falling labor share made headlines. The early contributors were Elsby, Hobijn, and Sahin (2013); Karabarbounis and Neiman (2013); and Piketty (2014), whose work motivated many other researchers to propose various explanations for the phenomenon.

Here we provide an overview of the proposed explanations. It is not meant to be an exhaustive list of all the papers on this topic. Rather, we focus on the three distinct, broad approaches that emerged in the literature.

\section{EXPLANATIONS IN THE LITERATURE}

\subsection{Technological Change: Two-Factor Models}

The first set of explanations posits that technological progress that unequally affects labor and capital (also known as biased or directed technological change) caused the decline in the labor share. This argument can be understood more clearly with a simple mathematical representation of the production side of the economy.

Consider a production function with two factors, labor $(L)$ and capital $(K)$ : 


$$
Y=F(K, L)
$$

where $Y$ is the output produced and $F$ is a homogeneous of degree 1 function. The elasticity of substitution between labor and capital $(\sigma)$ is defined in the usual way, where $W$ is the wage and $R$ is the user cost of capital:

$$
\sigma \equiv \frac{d \ln K / L}{d \ln W / R}
$$

The elasticity of substitution readily captures how factor income shares respond to changes in factor input prices: It is straightforward to see that

$$
\frac{d \ln (R K) /(W L)}{d \ln W / R} \lesseqgtr 0 \Leftrightarrow \sigma \lesseqgtr 1 .
$$

The labor share $(\ell)$ is defined as the share of compensation of employees in total value added:

$$
\ell \equiv \frac{W L}{P Y},
$$

where $P$ is the output price. Because of the homogeneity-of-degree- 1 assumption, $P Y=W L$ $+R K$, implying that the direction of the change in the labor share $\ell$ is the same as the direction of the change in $\frac{W L}{R K}$.

$R K$
For example, if technological changes make capital cheaper (that is, $\frac{W}{R}$ increases) and the elasticity of substitution between capital and labor $\sigma$ is greater than 1, then formula (3) implies that the labor income share falls.

This is the argument of Karabarbounis and Neiman (2013). They empirically document that the labor share fell across countries, and their estimated elasticity of substitution between labor and capital is indeed greater than 1 (about 1.25). They conclude that investment-specific technological change, which lowers the price of capital relative to consumption (Figure 2), caused the global decline of the labor share.

Piketty and Zucman (2014) make an analogous argument. If the elasticity of substitution $\sigma$ is greater than 1 , an increase in the capital-to-labor ratio $\left(\frac{K}{L}\right)$ will reduce the labor share. This follows from formula (5):

$$
\frac{d \ln (R K) /(W L)}{d \ln K / L} \lesseqgtr 0 \Leftrightarrow \sigma \lesseqgtr 1
$$

Since in the data the capital-to-output ratio increased and the labor share fell, Piketty and Zucman (2014) conclude that the elasticity of substitution between labor and capital is greater than 1 , especially in recent years.

Of course, these two papers are not the first to show that the labor share can fall because of the substitution between capital and labor. This point has been made by many earlier papers, such as those by Zeira (1998), Acemoglu (2003), Bentolila and Saint-Paul (2003), and Jones (2003), who emphasize the role of biased technological changes. The contribution of the 
Figure 2

Relative Price of Investment in the United States

Ratio of investment price to consumption price

1.6

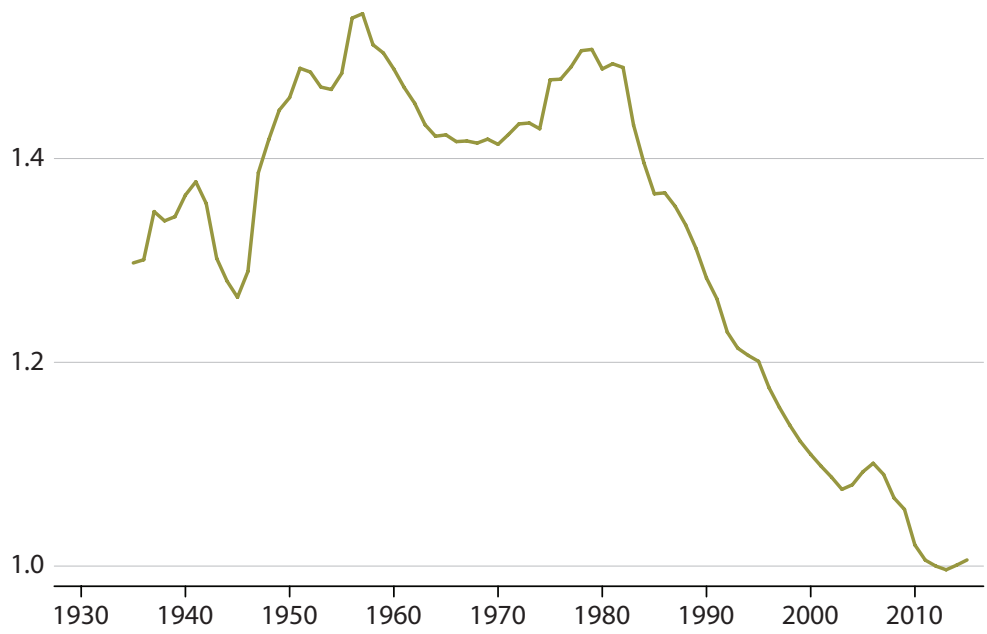

SOURCE: Authors' calculations based on data from NIPA.

Karabarbounis and Neiman (2013) and Piketty and Zucman (2014) papers is that they established the declining labor share as an empirical fact and then explained it with the capitallabor substitution channel.

However, it is not always easy to identify the elasticity of substitution parameter, and whether or not the elasticity is greater than 1 is not a settled matter. The direction and the magnitude of technological changes are difficult to observe and are hence typically constructed as a residual. Micro-level estimates of the elasticity use exogenous variations in factor prices, but a micro-level elasticity is not equal to the macro-level elasticity unless all the plants or firms have the same labor and capital intensities. Oberfield and Raval (2014) estimate the micro-level elasticity of substitution between labor and capital using plant-level data. They infer the aggregate elasticity of substitution using a model and the observed distribution of factor income shares across plants. Their estimated elasticity of substitution between labor and capital is less than 1, contrary to the above papers: They find that investment-specific technological changes or capital deepening cannot explain the declining labor share and that one needs to instead look to labor-augmenting technological change for an explanation.

\subsection{Mismeasured Labor Share}

Some studies argue that the fall of the labor share had been overestimated, which virtually obviates the need for an economic explanation.

Koh, Santaeulalia-Llopis, and Zheng (2019) show that the change in the coverage of capital in the System of National Accounts (SNA) is responsible for the trend decline of the labor 
share in the data. In an effort to better measure "intangible" capital, the SNA began to recognize software (SNA 1993) and research and development (SNA 2008) as investments rather than expenses; both of these are now called intellectual property products (IPP) capital. Once IPP capital was recognized as investment, it had to be included in value added and in the income account has since been counted as capital income. From the definition of the labor share (4), with a larger denominator but the same numerator, the labor share decreases mechanically. Because investment in IPP capital has been growing in the United States, as shown in Figure $3 \mathrm{~A}$, the inclusion of IPP in value added results in the fall of the measured labor share over time. Figure 3B shows the labor share with and without IPP: the green line is the labor share with IPP treated as investment (the current accounting method), and the orange line is the labor share with IPP treated as expenses (the pre-1999 accounting method). Since the labor share without IPP is more or less flat at least until the 2000s, the divergence between the two lines is evidence that IPP is an important factor in the decline of the labor share.

The argument so far is one of technological change (that is, the rising importance of IPP) and not mismeasurement. Koh, Santaeulalia-Llopis, Zheng (2019) then question the plausibility of assigning all IPP investment to capital income. Their view is that a significant portion of investment in intangible capital in reality should accrue to labor, but in many cases the compensation of workers employed to create intangible investment is in the form of equity claims and not counted as labor income. In other words, the labor compensation for IPP production is likely underestimated and the rising share of IPP has exacerbated this underestimation over time, generating the downward trend in the labor share in the data and the divergence between the green and the orange lines in Figure 3B.

In the same vein, Eisfeldt, Falato, and Xiaolan (2019) use compensation data for a subset of firms in the U.S. economy (i.e., those in Compustat) and demonstrate a rise in equity-based compensation (e.g., stock options) as a fraction of total employee compensation. Since equitybased compensation is not consistently counted as labor compensation in the National Income and Product Accounts (NIPA) of the U.S. Bureau of Economic Analysis (BEA), they argue that this underestimation of labor income could account for up to 60 percent of the observed decline of the labor share.

Another source of underestimation of labor income is the classification of self-employed income. To begin with, conceptually, it is not clear what fraction of a business owner's profit is compensation for their own labor or return on capital. Using U.S. tax data, Smith et al. (2019) show that top earners' entrepreneurial labor income is reported as "pass-through" business profit for tax reasons and counted as capital income, even though typical top earners are shown to derive the majority of their income from labor. Clearly, this is another source of underestimation of the labor share.

More broadly, adjusting for the labor income of the self-employed, Gutiérrez and Piton (forthcoming) show that the labor share has remained stable in most countries, with the exception of Canada and the United States.

In summary, a careful consideration of the data suggests that the labor share may not have fallen as much as previously reported. However, we note, even with adjustments, one clear pattern has not been explicitly mentioned in the literature: The labor share in the United States 


\section{Aum and Shin}

Figure 3

IPP and the Labor Share in the United States

A. IPP investment as a share of gross domestic income

IPP investment divided by gross domestic income

0.04

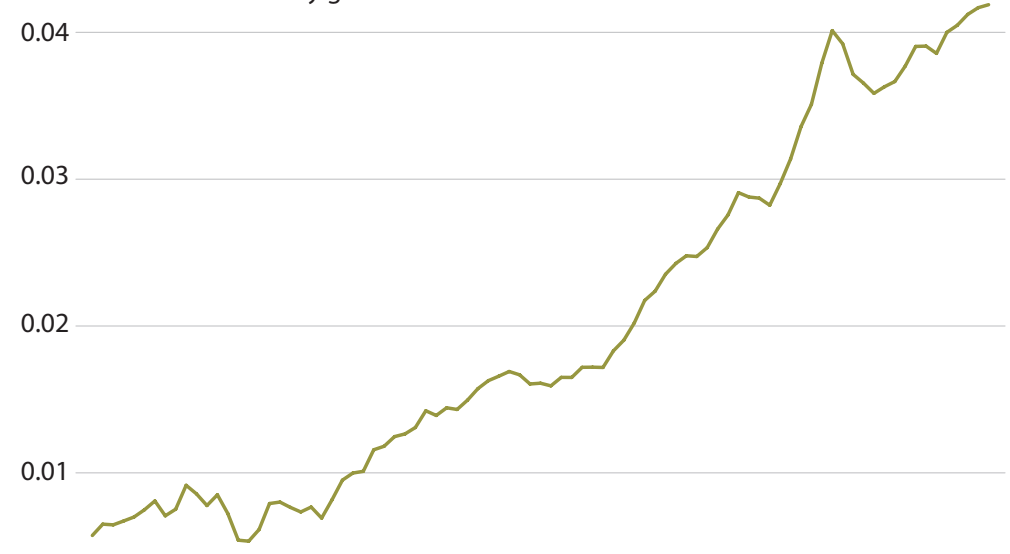

0

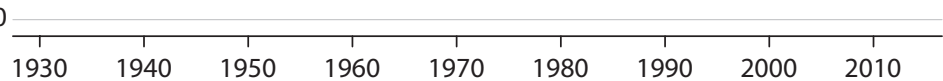

\section{B. Labor share with and without IPP}

Labor income with and without IPP as share of gross domestic income

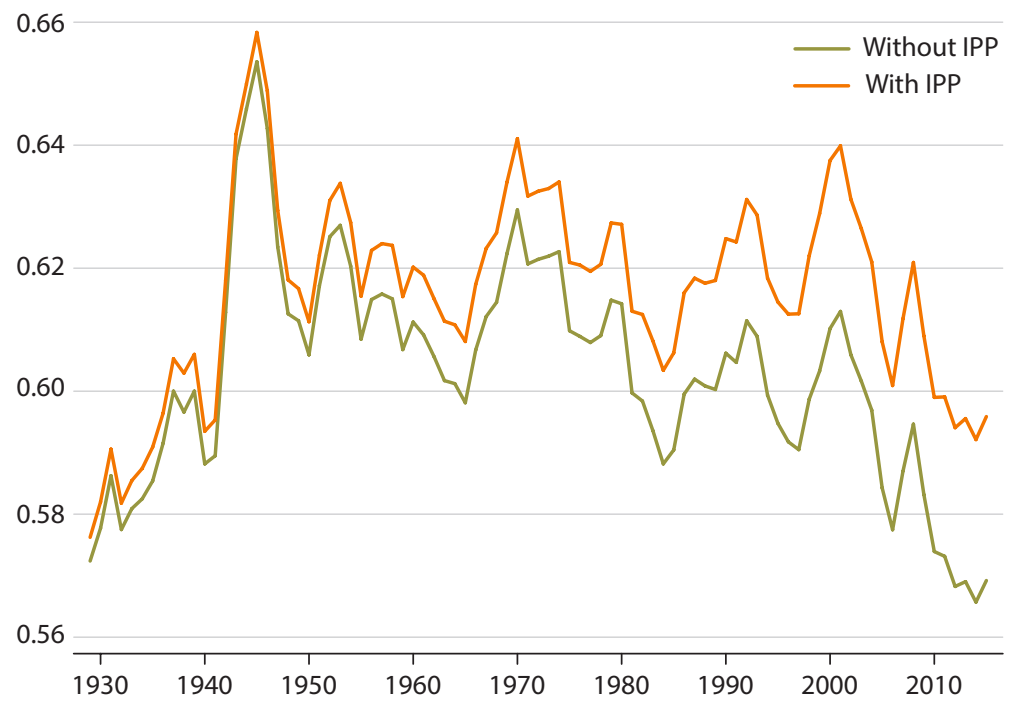

NOTE: Panel B: Labor share without IPP is compensation of employees divided by gross domestic income net of IPP investment.

SOURCE: Authors' calculations based on data from NIPA. 
Figure 4

\section{U.S. Labor Share Before and After Adjusting for Self-Employment}

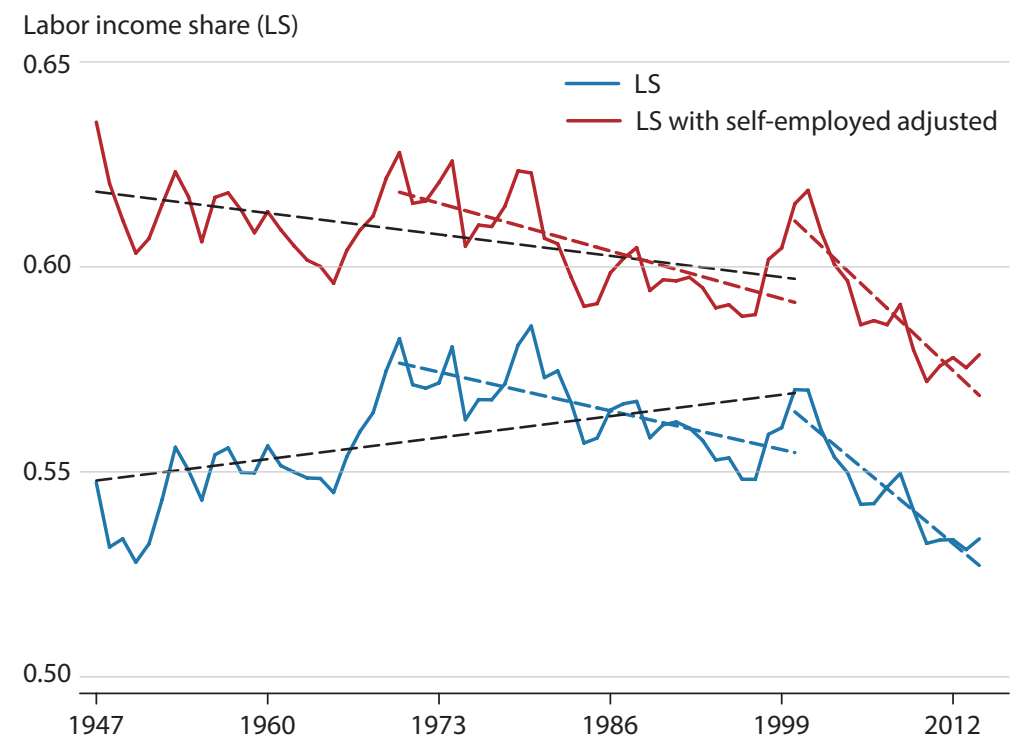

NOTE: The dashed lines are fitted linear trends.

SOURCE: Authors' calculations based on data from NIPA.

has fallen steadily since the 2000s. (The literature emphasizes the general downward trend since the 1980s.) This decline is shown in Figure 4 by the breaks in the linear trends and can be also seen in Figure 3B, where both the green (IPP as investment) and orange (IPP as expenses) lines show clear downward trends since the 2000s. We will revisit this timing of the trend break in the labor share in Section 3.

\subsection{Compositional Effects: Rising Market Concentration}

The final set of papers does not so much explain the declining labor share as link it to another dimension of economic inequality: the rising market power of large firms. Departing from the homogeneity assumption of Section 2.1, where value added gets divided into only labor income and capital income, we now allow for markup, or profit. Holding other things equal, a higher markup implies a smaller share of value added accruing to labor.

Unlike the above literature that typically relies on macro data, Autor et al. (forthcoming) use firm-level micro data for the United States and show that large firms have higher markups (and hence lower labor shares) than small firms, and that since the 1980s larger and moreproductive firms have gotten even larger and raised their market share. As economic activity has become more concentrated in a small set of "superstar" firms with low labor shares, the aggregate labor share has fallen. They point to globalization and technological changes as the possible causes of the rising market concentration. 
Kehrig and Vincent (2018) find similar patterns among manufacturing establishments (plants). They show that since the late 1960s, there has been a massive reallocation toward "hyper-productive" low-labor-share establishments in the U.S. manufacturing sector and that this reallocation accounts for all the decline in the labor share in the manufacturing sector.

This concludes our reading of the leading explanations in the literature for the declining labor share, and we now explore dimensions of the data that have not been carefully studied in the preceding papers.

\section{A NEW PERSPECTIVE ON THE DECLINING LABOR SHARE}

As summarized in the previous section, many studies have advanced our understanding of the decline of the labor share. However, as we noted for Figure 4, the decline has been more conspicuous since the 2000s, to which the preceding work did not pay particular attention: Again, the literature typically dates the beginning of the labor share decline to the early 1980s. In this section, we investigate three dimensions of the data-sectors, occupations, and types of capital-that could be particularly relevant to the recent trend break.

\subsection{Sectors}

At the sector level, the labor share declined mostly in the manufacturing sector, as pointed out by Alvarez-Cuadrado, Long, and Poschke (2018). This fact led some researchers to focus on manufacturing industries. For example, Acemoglu and Restrepo (2019) argue that automation caused the labor share to fall particularly in the manufacturing sector.

To be more precise, we write the aggregate labor share $(\ell)$ as the average of the labor shares in the manufacturing and service sectors, weighted by the value-added share of each sector:

$$
\ell=\frac{\mathrm{CE}_{M}+\mathrm{CE}_{S}}{\mathrm{VA}_{M}+\mathrm{VA}_{S}}=\underbrace{\frac{\mathrm{VA}_{M}}{\mathrm{VA}_{M}+\mathrm{VA}_{S}} \times \frac{\mathrm{CE}_{M}}{\mathrm{VA}_{M}}}_{\text {manufacturing }}+\underbrace{\frac{\mathrm{VA}_{S}}{\mathrm{VA}_{M}+\mathrm{VA}_{S}} \times \frac{\mathrm{CE}_{S}}{\mathrm{VA}_{S}}}_{\text {services }},
$$

where $\mathrm{CE}_{i}$ is the total compensation of employees (labor income) in sector $i=M, S$ and $\mathrm{VA}_{i}$ is the value added of sector $i . M$ stands for the manufacturing sector and $S$ for the service sector.

As shown in Figure 5C, the monotonic decline in the value-added weighted labor share of the manufacturing sector (blue line; first term in the right-hand side of equation (6)) coincides with the gentle downward trend in the aggregate labor share since 1980 (see Figure 4). However, we wish to draw attention to the trend break in the value-added weighted labor share of the service sector (red line; second term in the right-hand side of equation (6)) around 2000. Over the sample period, the decline in labor income in the manufacturing sector relative to aggregate value added had been partly offset by the rising relative importance of the service sector, but this partial offset ceased abruptly around 2000, after which the labor income in the service sector relative to aggregate value added remained more or less constant. This implies that the trend break in the aggregate labor share around 2000, and the most obvious decline in the labor share throughout the sample period, has more to do with what happened to the service sector than the manufacturing sector. 1 


\section{Figure 5}

\section{Value-Added and Labor Shares for Manufacturing and Services}

A. Value-added share $\frac{\mathrm{VA}_{i}}{\mathrm{VA}}$

Sectoral value-added share

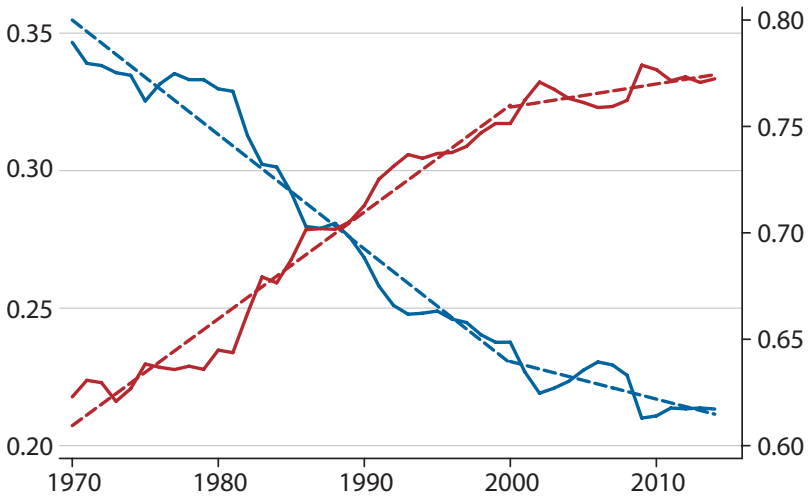

C. Value-added weighted labor share $\frac{\mathrm{CE}_{i}}{\mathrm{VA}}=\frac{\mathrm{VA}_{i}}{\mathrm{VA}} \times \frac{\mathrm{CE}_{i}}{\mathrm{VA}_{i}}$

Value-added weighted sector labor income share

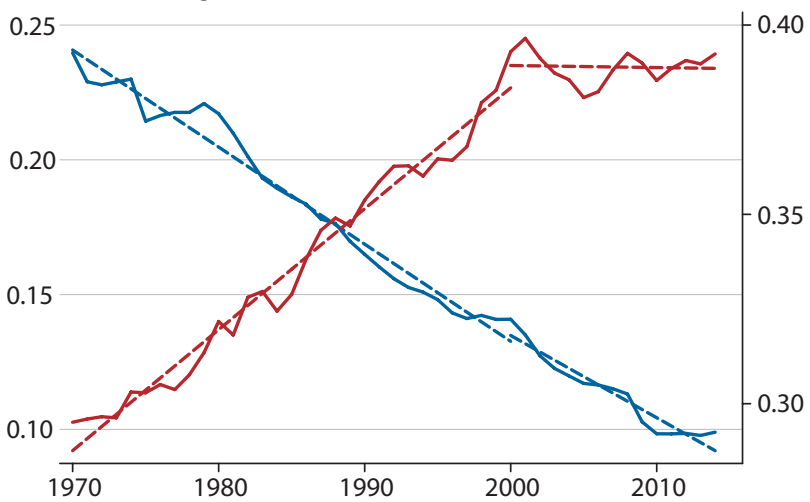

B. Sectoral labor share $\frac{\mathrm{CE}_{i}}{\mathrm{VA}_{i}}$

Sectoral labor income share

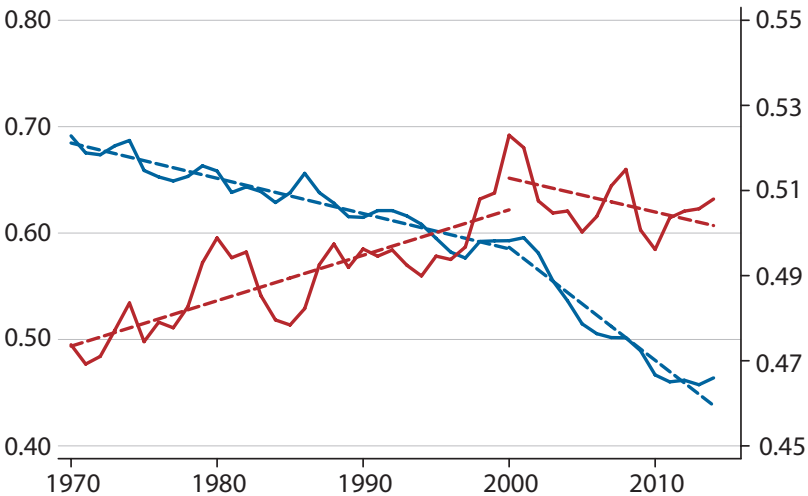

- Manufacturing (left axis)

Services (right axis)

NOTE: The dashed lines are fitted linear trends.

SOURCE: Authors' calculations based on data from NIPA and BEA industry accounts.

To summarize, while the weak downward trend in the aggregate labor share since 1980 is driven by the decline in the value-added weighted labor share of the manufacturing sector $\left(\frac{\mathrm{CE}_{M}}{\mathrm{VA}}\right)$, the cause for the break in the trend and the more conspicuous decline of the aggregate labor share in the 2000s may have been caused by changes in the service sector. 


\section{Aum and Shin}

\section{Figure 6}

\section{Occupational Contributions to Labor Share: Manual, Routine, and Cognitive}

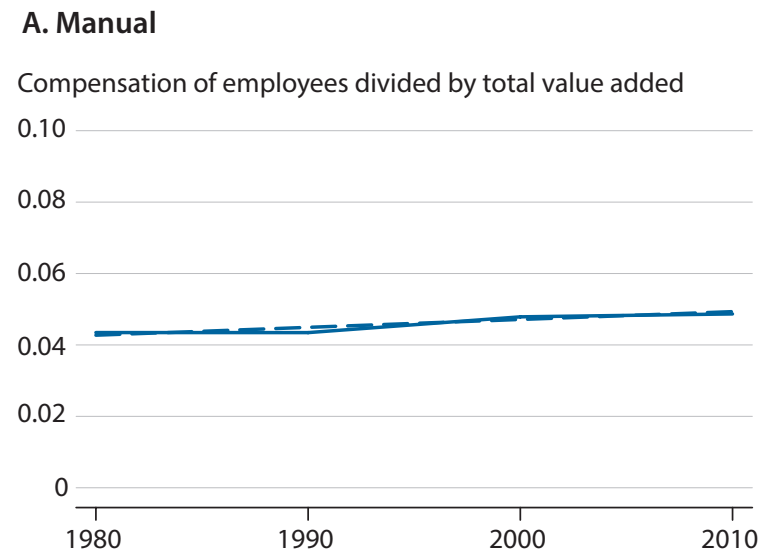

\section{B. Routine}

Compensation of employees divided by total value added

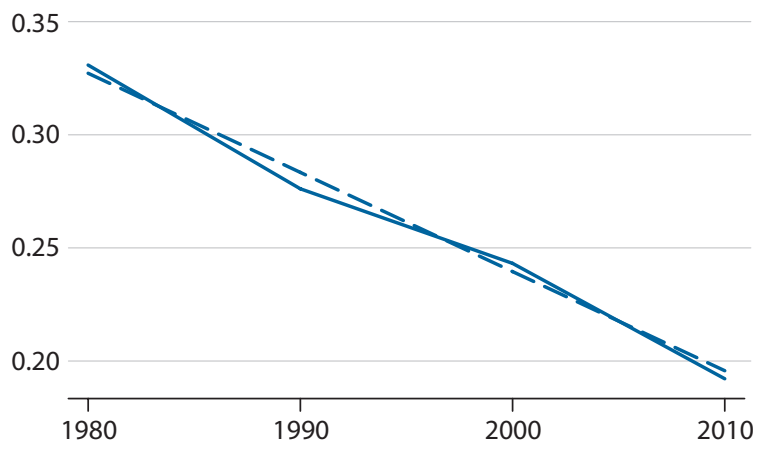

\section{Cognitive}

\section{All}

Compensation of employees divided by total value added
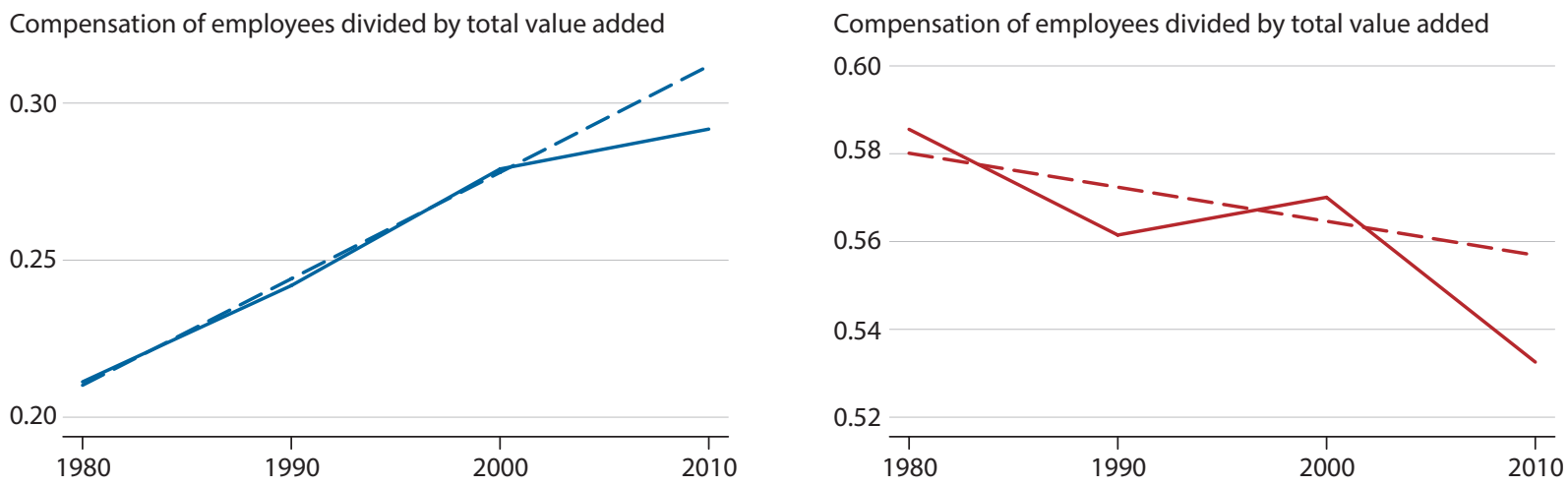

NOTE: Decomposition is $\ell_{j}=\frac{W_{j} L_{j}}{\mathrm{VA}}$ for $j=$ manual, routine, and cognitive. $W_{j} L_{j}$ is computed by $\mathrm{CE} \times \omega_{j}$, where CE is the total compensation of employees in NIPA and $\omega_{j}$ is the earnings share of occupational group $j$ obtained from the U.S. Census Bureau's American Community Survey. Panel D (All) plots $\frac{\mathrm{CE}}{\mathrm{VA}}$.

SOURCE: Authors' calculations based on data from NIPA and the U.S. Census Bureau's American Community Survey.

\subsection{Occupations}

At the occupation level, employment has polarized since 1980 (Acemoglu and Autor, 2011; Autor and Dorn, 2013; and Lee and Shin, 2017). The most widely accepted explanation for this polarization is that recent technological changes, especially automation technology, have replaced routine or middle-skill occupations. This replacement is a form of the substitution of labor with capital, discussed in Section 2.1, and can explain the labor share decline. Acemoglu and Restrepo (2019) introduce a task-based model in which technological progress enables capital to replace labor in certain tasks and argue that the displacement effect of auto- 
Figure 7

\section{Share of Software and Hardware Investment in Non-Residential Investment in the United States}

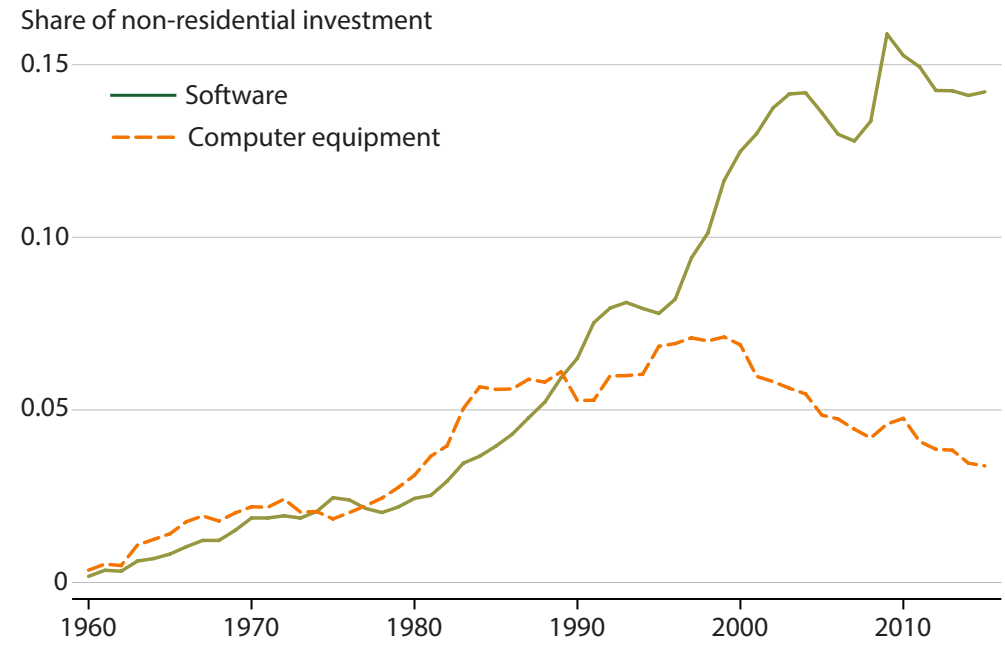

SOURCE: Authors' calculations based on data from NIPA.

mation has caused the fall of the labor share since the 1980s, especially through the fall in routine jobs.

In contrast, in order to understand the conspicuous downward trend in the labor share since 2000, we move our focus to another occupational group: cognitive-intensive, or highskill, occupations. We decompose the aggregate labor share into occupational groups. However, because we do not have value added by occupation, we divide occupation-level total labor compensation by the aggregate value added ( $\frac{W_{j} L_{j}}{\mathrm{VA}}$, where $j$ indexes occupations). $\underline{2}$

From the occupational contributions to the labor share, shown in Figure 6, we see that the trend break in the aggregate labor share around 2000 can be entirely attributed to the stagnation of cognitive-intensive occupations, although routine-intensive occupations have been responsible for the gentle, longer-run downward trend.

\subsection{Software}

Given the above findings, the natural next step is to ask what changed since 2000 for the cognitive-intensive (rather than routine) occupations and the service (rather than manufacturing) sector. Our work suggests that the rise of software investment can potentially explain the sector- and occupation-level labor share trends after 2000.

The rise of information technology (IT) since 1980, both hardware and software, has gotten much attention in the literature. However, it is not as well known that hardware and software have exhibited diverging patterns since 2000. Figure 7 depicts shares of software and computer equipment investment in total non-residential investment. We see a dramatic rise 


\section{Aum and Shin}

Figure 8

\section{Software Use, Hardware Use, and Share of Cognitive-Intensive Occupations Across Occupational Skill Percentiles}

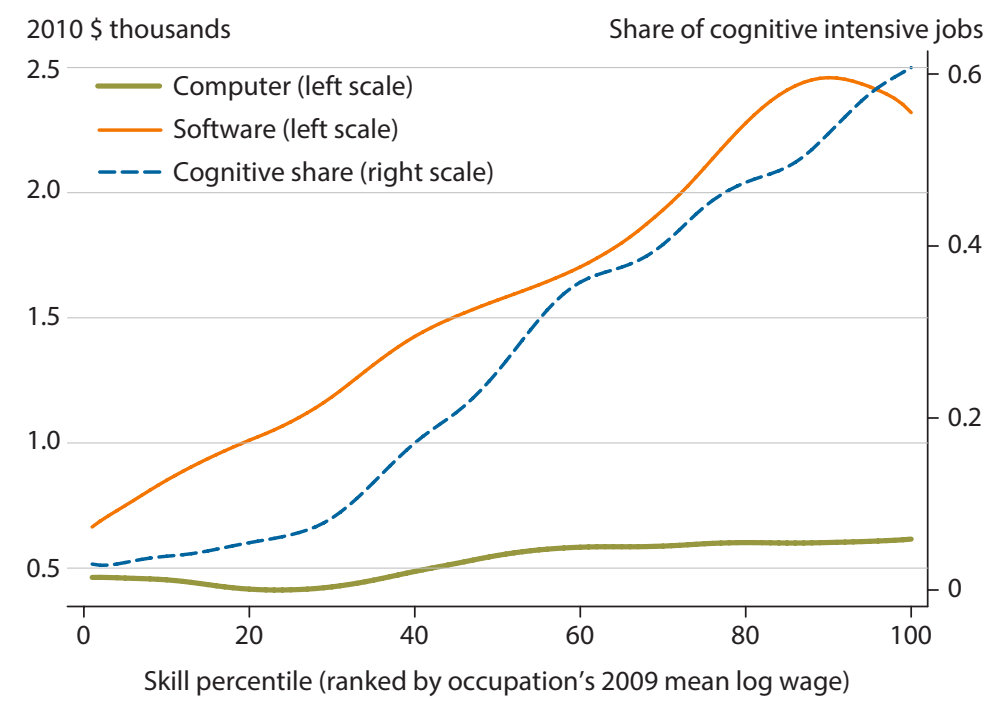

NOTE: One unit on the horizontal axis represents a group of occupations representing 1 percent of employment in 2010, where occupations are sorted by average hourly wage in 2009 (from low to high). Software use is calculated by assigning an investment value of software to each occupation according to the number of software used by the occupation, obtained from the O*NET Tools and Technology database. The share of cognitive-intensive occupations is a fraction of workers in occupations that are above the 66th percentile of occupational rank of cognitive task intensity, computed following Acemoglu and Autor (2011). See Aum (2019) for details.

SOURCE: Authors' calculations based on data from NIPA, O*NET Tools and Technology, and the U.S. Census Bureau's American Community Survey.

of software investment (green line) relative to computer equipment investment (orange line) beginning around the late $1990 \mathrm{~s} . \underline{3}$

The growth of software investment closely tracks the increased demand for cognitiveintensive occupations. Aum (2019) shows that software use is concentrated among cognitiveintensive occupations (shown as Figure 8 here). He argues that, however, software innovation could eventually lead to a lower demand for cognitive-intensive occupations. Intuitively, software innovation makes cognitive-intensive occupations relatively more productive than other occupations, because they use software more intensively. When occupations are complementary to one another, higher relative productivity of cognitive-intensive occupations increases the demand for other occupations. Furthermore, if software substitutes for cognitiveintensive occupations, software innovation will reduce the labor income share, especially for cognitive-intensive occupations, consistent with the evidence in Figure 6. ${ }^{4}$ Note that these arguments rely on the complementarity among occupations and the substitutability between cognitive-intensive occupations and software.

Turning to the sector level, we exploit industry-level variations across 60 BEA industry classifications to examine whether the decline in the labor share between 2000 and 2010 is 


\section{Table 1}

Relationship Between Changes in the Labor Share and Potential Explanatory Variables, Across Manufacturing Industries

\begin{tabular}{|c|c|c|c|c|c|c|c|}
\hline \multirow[b]{2}{*}{ Import competition } & \multicolumn{7}{|c|}{ Changes in labor share between 2000 and 2010} \\
\hline & $\begin{array}{c}-0.023^{*} \\
(0.013)\end{array}$ & & & & & & $\begin{array}{c}0.003 \\
(0.016)\end{array}$ \\
\hline Intermediate offshoring & & $\begin{array}{c}-0.020 \\
(0.014)\end{array}$ & & & & & $\begin{array}{c}0.003 \\
(0.015)\end{array}$ \\
\hline Task offshorability & & & $\begin{array}{c}-0.023 \\
(0.015)\end{array}$ & & & & $\begin{array}{c}-0.010 \\
(0.017)\end{array}$ \\
\hline Routineness & & & & $\begin{array}{c}-0.011 \\
(0.011)\end{array}$ & & & $\begin{array}{c}0.007 \\
(0.012)\end{array}$ \\
\hline Computer intensity & & & & & $\begin{array}{c}-0.049^{* *} \\
(0.018)\end{array}$ & & $\begin{array}{c}-0.024 \\
(0.021)\end{array}$ \\
\hline Software intensity & & & & & & $\begin{array}{l}-0.029^{* * *} \\
(0.007)\end{array}$ & $\begin{array}{l}-0.025^{* * *} \\
(0.012)\end{array}$ \\
\hline$R^{2}$ & 0.140 & 0.089 & 0.103 & 0.047 & 0.264 & 0.451 & 0.502 \\
\hline
\end{tabular}

NOTE: Standard errors are in parentheses. ${ }^{*} p<0.1,{ }^{* *} p<0.05,{ }^{* * *} p<0.01$.

SOURCE: Authors' calculations based on data from BEA input-output tables, BEA industry accounts, O*NET Tools and Technology, and the U.S.

Census Bureau's American Community Survey.

\section{Table 2}

Relationship Between Changes in the Labor Share and Potential Explanatory Variables, Across Service Industries

\begin{tabular}{|c|c|c|c|c|c|c|c|}
\hline \multirow[b]{2}{*}{ Import competition } & \multicolumn{7}{|c|}{ Changes in labor share between 2000 and 2010} \\
\hline & $\begin{array}{c}-0.023 \\
(0.027)\end{array}$ & & & & & & $\begin{array}{c}0.000 \\
(0.022)\end{array}$ \\
\hline Intermediate offshoring & & $\begin{array}{c}-0.022 \\
(0.023)\end{array}$ & & & & & $\begin{array}{c}0.002 \\
(0.021)\end{array}$ \\
\hline Task offshorability & & & $\begin{array}{c}-0.014 \\
(0.018)\end{array}$ & & & & $\begin{array}{c}0.007 \\
(0.019)\end{array}$ \\
\hline Routineness & & & & $\begin{array}{c}0.015 \\
(0.018)\end{array}$ & & & $\begin{array}{c}0.020 \\
(0.017)\end{array}$ \\
\hline Computer intensity & & & & & $\begin{array}{r}-0.018 \\
(0.019)\end{array}$ & & $\begin{array}{c}0.012 \\
(0.015)\end{array}$ \\
\hline Software intensity & & & & & & $\begin{array}{c}-0.134^{* * *} \\
(0.022)\end{array}$ & $\begin{array}{l}-0.149 * * * \\
(0.027)\end{array}$ \\
\hline$R^{2}$ & 0.022 & 0.027 & 0.017 & 0.021 & 0.027 & 0.524 & 0.585 \\
\hline
\end{tabular}

NOTE: Standard errors are in parentheses. ${ }^{*} p<0.1,{ }^{* *} p<0.05,{ }^{* * *} p<0.01$.

SOURCE: Authors' calculations based on data from BEA input-output tables, BEA industry accounts, O*NET Tools and Technology, and the U.S. Census Bureau's American Community Survey. 
associated with six factors (explanatory variables): import competition, intermediate offshoring, task offshorability, routineness, computer (hardware) intensity, and software intensity.

Tables 1 and 2 show the regression coefficients of each of the six explanatory variable for the manufacturing and service industries, respectively. We normalized the variables (i.e., subtracted the mean and divided by the standard deviation) so that the coefficient estimates are comparable.

For manufacturing industries, import competition, computer intensity, and software intensity show significance. However, when all variables are included in the regression (last column, Table 1), only software intensity remains significant. For services, software intensity is the only variable that shows significance (Table 2). Since the flattening of the labor share in services contributed the most to the sharp drop in the aggregate labor share after the late 1990s, this analysis suggests that software can be an important part of the explanation for the trends in the labor share.

\section{CONCLUDING REMARKS}

The decline of the labor share has been actively studied in recent years. We have reviewed the leading explanations for the decline of the labor share in the literature. However, the literature emphasizes the gentle decline since the 1980s and has been silent about the more stark fall since 2000. Taking a detailed look at sectors, occupations, and types of capital, we provide evidence that service industries and cognitive occupations merit more attention in order to fully understand the trends in the labor share. In particular, separating software investment from other types of capital promises to be a fruitful avenue for research. 


\section{NOTES}

1 From the decomposition $\Delta\left(\omega_{s} L S_{S}\right)=\overline{L S}_{S} \Delta \omega_{s}+\bar{\omega}_{s} \Delta L S_{S^{\prime}}$ we find that the change in the sectoral value-added share and the change in the sectoral labor share contributed nearly equally to the flattening of the value-added weighted labor share of services.

$\underline{2}$ We classify occupational groups into cognitive, routine, and manual occupations based on the one-digit Standard Occupational Classification codes of the U.S. Bureau of Labor Statistics. Cognitive occupations are managers, professionals, and technicians. Routine occupations are machine operators, transportation workers, sales and office personnel, mechanics, and miners and production workers. Manual occupations are low-skill service occupations.

3 Hardware and software facilitate workers' tasks differently. Figure 8 demonstrates that software usage varies across occupations (correlated with cognitive task intensity) much more than computer usage (which is basically whether a computer is used or not).

4 Aum, Lee, and Shin (2018) model computer capital (both hardware and software) separately from other types of capital and allow the elasticity of substitution between labor and computers to differ from that between labor and other types of capital. Their calibration strategy did not target the labor share, but the elasticity of substitution between labor and computers came out greater than 1.

$\underline{5}$ Each variable is computed as follows. Import competition for industry $i$ is import i $_{i} /$ output $_{i}+$ import $_{i}-$ export $_{i}$ ). Intermediate offshoring is intermediate use of $j$ in $i$ times (import ${ }_{j} /$ output $_{j}$ ). Task offshorability is the share of offshorable jobs in industry $i$, where offshorable jobs are those with an occupational ranking of offshorability greater than the 66th percentile (Autor and Dorn, 2013). Routineness is the share of occupations in industry $i$ with an occupational ranking of routine-task intensity greater than the 66th percentile (Acemoglu and Autor, 2011). Computer intensity is computer hardware investment divided by industry value added. Finally, software intensity is software investment divided by industry value added.

\section{REFERENCES}

Acemoglu, D. "Labor- and Capital-Augmenting Technical Change." Journal of the European Economic Association, 2003, 1, pp. 1-37; https://doi.org/10.1162/154247603322256756.

Acemoglu, D. and Autor, D. "Skills, Tasks and Technologies: Implications for Employment and Earnings,." in David Card and Orley Ashenfelter eds., Handbook of Labor Economics, Volume 4. Elsevier, 2011, pp. 1043-171.

Acemoglu, D. and Restrepo, P. "Automation and New Tasks: How Technology Displaces and Reinstates Labor." Journal of Economic Perspectives, 2019, 33, pp. 3-30; https://doi.org/10.1257/jep.33.2.3.

Alvarez-Cuadrado, F.; Long, N.V. and Poschke, M. "Capital-Labor Substitution, Structural Change and the Labor Income Share." Journal of Economic Dynamics and Control, 2018, 87, pp. 206-31; https://doi.org/10.1016/j.jedc.2017.12.010.

Aum, S. "The Rise of Software and Skill Demand Reversal." Unpublished manuscript, 2019.

Aum, S.; Lee, S.Y.T. and Shin, Y. "Computerizing Industries and Routinizing Jobs: Explaining Trends in Aggregate Productivity." Journal of Monetary Economics, 2018, 97, pp. 1-21; https://doi.org/10.1016/j.jmoneco.2018.05.010.

Autor, D.H. and Dorn, D. "The Growth of Low-Skill Service Jobs and the Polarization of the U.S. Labor Market." American Economic Review, 2013, 103, pp. 1553-97; https://doi.org/10.1257/aer.103.5.1553.

Autor, D.H.; Dorn, D.; Katz, L.F.; Patterson, C. and Van Reenan, J. "The Fall of the Labor Share and the Rise of Superstar Firms." Quarterly Journal of Economics (forthcoming).

Bentolila, S. and Saint-Paul, G. "Explaining Movements in the Labor Share." Contributions in Macroeconomics, 2003.

Eisfeldt, A.L., Falato, A. and Xiaolan, M.Z. "Human Capitalists." Unpublished manuscript, 2019; https://doi.org/10.2139/ssrn.3375849.

Elsby, M.W.L.; Hobijn, B. and Sahin, A. "The Decline of the U.S. Labor Share." Brookings Papers on Economic Activity, 2013, pp. 1-52; https://doi.org/10.1353/eca.2013.0016. 


\section{Aum and Shin}

Gutiérrez, G. and Piton, S. "Revisiting the Global Decline of the (Non-Housing) Labor Share." American Economic Review: Insights (forthcoming).

Jones, C. "Growth, Capital Shares, and a New Perspective on Production Functions." Working paper, 2003.

Kaldor, N. "A Model of Economic Growth." Economic Journal, 1957, 67, pp. 591-624; https://doi.org/10.2307/2227704.

Karabarbounis, L. and Neiman, B. "The Global Decline of the Labor Share." Quarterly Journal of Economics, 2013, 129, pp. 61-103; https://doi.org/10.1093/qje/qjt032.

Kehrig, M. and Vincent, N. “The Micro-Level Anatomy of the Labor Share Decline." NBER Working Paper 25275, National Bureau of Economic Research, 2018; https://doi.org/10.3386/w25275.

Keynes, J.M. "Relative Movements of Real Wages and Output." Economic Journal, 1939, 49, pp. 34-51; https://doi.org/10.2307/2225182.

Koh, D.; Santaeulalia-Llopis, R. and Zheng, Y. "Labor Share Decline and Intellectual Property Products Capital." Unpublished manuscript, 2019.

Kuznets, S. "Long-Term Changes in the National Income of the United States of America since 1870." Review of Income and Wealth, 1952, 2, pp. 29-241.

Lee, S.Y. and Shin, Y. “Horizontal and Vertical Polarization: Task-Specific Technological Change in a Multi-Sector Economy." NBER Working Paper 23283, National Bureau of Economic Research, 2017.

Oberfield, E. and Raval, D. "Micro Data and Macro Technology." NBER Working Papers 20452, National Bureau of Economic Research, 2014

Phelps Brown, E.H. and Hart, P.E. "The Share of Wages in National Income." Economic Journal, 1952, 62, pp. 253-77; https://doi.org/10.2307/2227004.

Piketty, T. Capital in the Twenty-First Century. Harvard University Press, 2014; https://doi.org/10.4159/9780674369542.

Piketty, T. and Zucman, G. "Capital Is Back: Wealth-Income Ratios in Rich Countries 1700-2010." Quarterly Journal of Economics, August 2014, 129(3), pp. 1255-310; https://doi.org/10.1093/qje/qju018.

Smith, M.; Yagan, D.; Zidar, O.M. and Zwick, E. "Capitalists in the Twenty-First Century." NBER Working Paper 25442, National Bureau of Economic Research, 2019; https://doi.org/10.3386/w25442.

Zeira, J. "Workers, Machines, and Economic Growth." Quarterly Journal of Economics, 1998, 113(4), pp. 1091-117; https://doi.org/10.1162/003355398555847. 